\title{
Secondary Sjögren's syndrome and disease activity of rheumatoid arthritis
}

Daniel C. Antero ${ }^{1}$, André G. M. Parra², Fernando H. Miyazaki², Marcelo Gehlen ${ }^{3}$, Thelma L Skare ${ }^{4}$

${ }^{1} \mathrm{MD}$, Internal Medicine Specialist; Resident Physician in Rheumatology at Hospital Universitário Evangélico de Curitiba (HUEC), Curitiba, PR

${ }^{2} \mathrm{MD}$, Resident Physician in the Ophtalmology Service at HUEC, Curitiba, PR

${ }^{3} \mathrm{PhD}$ in Surgery Principles and Physician at the Ophtalmology Residency Service at HUEC, Curitiba, PR

${ }^{4} \mathrm{PhD}$ in Surgery Principles and Chief of the Rheumatology Service at HUEC, Curitiba, PR

Study conducted at Serviços de Reumatologia e de Oftalmologia do Hospital Universitário Evangélico de Curitiba, Curitiba, PR

\section{SUMMARY}

Objective: To study the relationship of the presence of secondary SS with disease activity, duration in RA. Methods: Eighty two patients with RA were submitted to Schirmer test, minor salivary gland biopsy, questionnaire on sicca symptoms, DAS-28 4v determination. Results: In this population, 20 (24.3\%) patients fulfilled the American-European classification criteria for secondary SS. No relation could be found between the presence of secondary SS and disease activity $(\mathrm{p}=0.31)$ and RA duration $(\mathrm{p}=0.95)$. Conclusion: Appearance of Secondary SS in RA patients is independent of RA duration or activity.

Keywords: Arthritis, rheumatoid; dry eye syndromes; inflammation.

\section{Resumo}

\section{Síndrome de Sjögren secundária e atividade da artrite reumatoide}

Objetivo: Estudar a associação entre presença de SS secundária e atividade e duração da artrite reumatoide. Métodos: Oitenta e dois pacientes com artrite reumatoide foram submetidos ao teste de Schirmer, biópsia de glândula salivar menor, questionários acerca de sintomas de secura e determinação do DAS28 4v. Resultados: Nesta população, 20 $(24,3 \%)$ dos pacientes preenchiam os Critérios Americanos Europeus para classificação de SS Secundário. Nenhuma associação foi encontrada entre presençade SS secundário $e$ atividade da doença $(p=0.31)$ e duração da doença $(p=0.95)$. Conclusão: $\mathrm{O}$ aparecimento de SS secundário em AR é independente da duração e atividade da AR.

Unitermos: Artrite reumatoide; síndromes do olho seco; inflamação. 


\section{INTRODUCTION}

Sjögren's syndrome (SS) is a chronic autoimmune inflammatory disease that affects lachrymal and salivary glands causing mucous dryness that affects mainly middle aged women ${ }^{1}$. SS can be a primary or a secondary disease when it is associated with other autoimmune disorders such as scleroderma and rheumatoid arthritis $(\mathrm{RA})^{2}$. Superimposed SS in RA is an interesting finding. There is an important role of B cells and type I interferon in primary $\mathrm{SS}^{2,3}$ in contrast to the predominance of Th17 cytokines in $\mathrm{RA}^{4}$. As the physiopathology of these two diseases is distinct, it is possible to suggest that patients with RA and secondary SS have two different diseases or that RA secondary SS has a different physiopathology than the primary form. In this context we aimed to study if RA disease activity or severity have any association with occurrence of secondary Sjogren's syndrome.

\section{Methods}

This study was approved by the Committee for Ethics in Research of our institution and all participants signed consent. To participate in the study patients had to present at least four criteria of the American College of Rheumatic Diseases for $\mathrm{RA}^{7}$. The included patients were selected from a single Rheumatology Clinic (Evangelic University Hospital) chosen according to appointment order and willingness to participate in the study. We excluded patients with ophthalmologic complications such as scleritis, episcleritis, scleromalacia, those with prior eye surgery and contact lenses users or those taking medications such as antidepressants, anticholinergics, antihistamine, diuretics, etc, those with hepatitis $\mathrm{C}$ or $\mathrm{HIV}$ infection or prior irradiation of the neck.

All included patients had Schirmer test done according to standard recommendations and we considered a patient to be with definitive dry eye when values were equal or under $5 \mathrm{~mm}$ in at least one eye $\mathrm{e}^{8}$. Biopsy of minor salivary gland was done in all included patients and sections were stained by hematoxylin-eosin and considered positive when a focus of 50 lymphocytes $/ 4 \mathrm{~mm}^{2}$ was found ${ }^{9}$. Salivary gland biopsy was read by a blinded pathologist. Simultaneously with eye tests and minor salivary gland biopsy, patients had DAS-28 $4 \mathrm{v}^{10,11}$ and also answered a questionnaire on sicca symptoms (oral and ocular). DAS 28 is a measurement of RA disease activity that takes into account number of swollen and tender joints, a measurement of general health by the patients and values of sedimentation rate. Patients with DAS28 values under 2.6 are considered under remission, with values between 2.6 and 3.1 as having mild disease activity; with values between 3.2 and 5.1 as having moderate activity and over 5.1 with high disease activity.

Patient's joint count was done by just one rheumatologist. Charts were reviewed for demographic data,
$\mathrm{HAQ}^{12}$ and autoantibody profile (latex, anti CCP, anti Ro, Anti La).

To consider a RA patient as having secondary SS it was necessary to fulfill the American European Criteria for secondary $\mathrm{SS}^{13,14}$.

Data were grouped in contingency and frequency table. For association studies we used the chi-squared test for nominal data and unpaired $t$ and Mann-Whitney tests for numeric data. The significance adopted was $5 \%$.

\section{Results}

Eighty two patients were included: 72 women and 10 men with mean age of $51.8 \pm 10.0$ years and mean disease duration of $10.2 \pm 7.0$ years. In this sample $50 / 82$ (75\%) had rheumatoid factor; $25 / 35$ (71.4\%) had a positive anti- CCP; 25/82 (30.4\%) were ANA positive; 6/82 (7.3\%) had anti-Ro and 1/82 (1.2\%) had anti-La. RA treatment was done with prednisone in 62/82 (75.6\%); antimalarials in $63 / 82(76.8 \%)$; methotrexate in $71 / 82$ (86.5\%), leflunomide in $33 / 82(40.2 \%)$, sulphasalazine in $11 / 82(13.4 \%)$, anti TNF- $\alpha$ in $8 / 82$ (9.7\%) and rituximab in $2 / 82(2.4 \%)$. Dry eye complaints were found in $47 / 82$ (57.3\%) and dry mouth in 29/82 (35.3\%); 46/82 (56.0\%) had a positive minor salivary gland biopsy. The Schirmer test result varied between 0 to $35 \mathrm{~mm}$ (mean $14.3 \pm 10.1 \mathrm{~mm}$ ) and was under $5 \mathrm{~mm}$ in $34 / 82(41.4 \%)$. Five $(6 \%)$ patients had also ceratitis. DAS-28 varied from 0.6 to 6.99 (mean $3.22 \pm 1.41$ ). Twenty patients $(24.39 \%$ ) fulfilled the American-European criteria for Secondary SS.

Studying DAS-28 according to the presence of secondary SS, we found a mean value of $2.81 \pm 1.14$ in those with SS and $3.35 \pm 1.47$ in those without it $(\mathrm{p}=0.13)$. The mean value of DAS-28 in patients with Schirmer test under $5 \mathrm{~mm}$ was $3.1 \pm 1.3$ and in those with values higher than $5 \mathrm{~mm}$ it was $3.3 \pm 1.4(\mathrm{p}=0.50)$. Presence of Secondary SS according to DAS-28 is shown in Figure 1. Mean DAS-28 value in patients with subjective symptoms for dry eyes was $3.35 \pm 1.58$ and in those without it $3.04 \pm 1.13(\mathrm{p}=0.31)$.

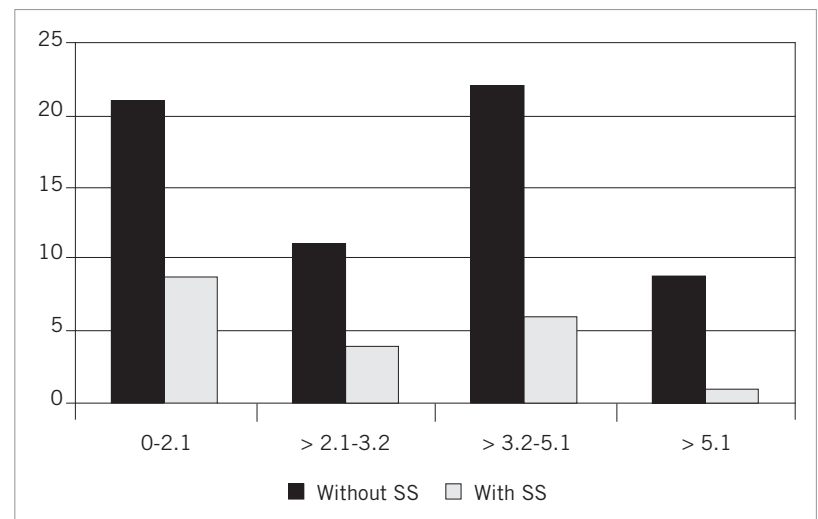

Figure 1 - Presence of secondary Sjögren's syndrome according to DAS-28 in 82 patients with rheumatoid arthritis $(p=0.61)$. 
Table 1 shows data in RA patients with and without Secondary SS Syndrome.

\section{Discussion}

The presence of sicca symptoms was high in the studied population although only $24 \%$ of patients fulfilled criteria for secondary SS. The high prevalence of dry eyes in RA patients without fulfilling the diagnostic criteria for secondary SS has been noticed by Fujita et al. ${ }^{15}$ who found it in $90 \%$ of non-SS RA patients. In their study of $72 \mathrm{RA}$ Japanese patients, just 10\% of them had Secondary SS. The presence of secondary SS in RA has been found to be higher in other studies. Cimmino et al. ${ }^{5}$ found it in $17.5 \%$ of Italian RA patients and Martinez Castro et al. ${ }^{6}$, in 55\% of Spanish RA population. This high variability may be due to the genetic background of the studied population and methods chosen to evaluate glandular dysfunction.

Secondary SS is usually included as an extra-articular manifestation of rheumatoid arthritis ${ }^{16}$. According to Fox et al. ${ }^{17}$, SS associated with RA occurs in a different genetic background than the primary disease (HLA DR4) and this author suggests that SS associated with RA has a different pathogenetic process than that associated with lupus and with scleroderma. As we found in the present work, this later author noticed that ocular symptoms of dryness are more common than oral ones in RA patients.

Our results also show that neither secondary SS occurrence nor eye sicca subjective and objective findings have any relation to disease duration. A study done in Spain found that patients with RA duration up to 10 years had a prevalence of secondary SS of $17 \%$ and after 30 years it was as high as $25 \%{ }^{18}$. This relationship with disease duration was not confirmed by Uhlig et al. ${ }^{19}$ but was present in a Study done in the United Kingdom ${ }^{20}$.

The association between secondary SS and disease activity was also studied by Fujita et al. ${ }^{15}$ who found that RA activity had no significant correlation with the presence of dry eye, however it had some relationship in those patients that fulfilled the diagnosis of secondary SS. Although we did not graduate severity of sicca findings, we could not find a higher RA activity measured by DAS- 28 in patients with secondary SS when compared to those without it in the present study. No relationship could also be established with functional index. Wolfe et al. ${ }^{21}$, although they did not study Secondary SS, found that sicca symptoms are more common in patients with RA with increased HAQ scores, pain and global severity as well as total joint replacement and work disability.

According to the present findings rheumatologists and ophthalmologists should be aware of high indices of sicca symptoms in RA and seek for secondary SS independently of the activity or duration of rheumatoid arthritis.

\section{REFERENCES}

1. Pillimer SR Sjogren's syndrome. In: Klippel JH, Crofford LJ, Stone JH, Weyand CM, editors. Primer on the rheumatic diseases. Atlanta: Arthritis Foundation; 2001. p.377-84.

2. Fox RI, Liu AY. Sjogren's syndrome in dermatology. Clin Dermatol. 2006;24:393-413.

3. Dorner T. Crossroads of B cell activation in autoimmunity: rationale of targeting B cells. J Rheumatol Suppl. 2006;77:3-11.

4. Kvien TK, Scherer HU, Burmester GR. Rheumatoid arthritis. In: Bijlsma JWJ, editor. Eular compendium on rheumatic diseases London: BMJ Publishing Group London; 2009. p.61-80.

5. Cimmino MA, Salvarani C, Macchioni P, Montecucco C, Fossaluzza V, Mascia MT. Extra-articular manifestations in 587 Italian patients with rheumatoid arthritis. Rheumatol Int. 2000;19:213-7.

6. Martinéz-Castro E, Olivé Marqués A, Bonet Llorach M, Carbonell Abeló J, Cobo Valeri E, Juncà Valdor S. Rheumatoid arthritis and SS: special reference to the course time of rheumatoid arthritis. Med Clin (Barc). 1990;94:655-9.

7. Arnett FC, Edworthy SM, Bloch DA, Mc Shane DJ, Fries JF, Cooper NS et al. The American Rheumatology Association 1987 revised criteria for the classification of rheumatoid arthritis. Arthritis Rheum. 1988;31:315-24

8. Afonso AA,Monroy D, Stern ME, Feuer WJ, Tseng SC, Pflugfelder SC et al. Correlation of tear fluorescein clearance and Schirmer test scores with ocular irritation symptoms. Ophtalmology 1999;106:803-10.

9. Daniels TE, Whitcher JP. Association of patterns of labial salivary gland inflammation with kerotoconjuctivitis sicca. Analysis of 618 patients with suspected Sjögren's syndrome. Arthritis Rheum. 1994;37:869-77.

10. Mäkinen H, Kautiainen H, Hannonen P, Sokka T. Is DAS-28 an appropriate tool to assess remission in rheumatoid arthritis? Ann Rheum Dis. 2005;64:1410-3.

11. Fransen J, van Riel PLCM. DAS remission cut points. Clin Exp Rheumatol. 2006; 24(Suppl 43):S29-S32.

12. Ramey DR, Raynauld JP, Fries JF. The health assessment questionnaire 1992: status and review. Arthritis Care Res. 1992;5:119-29.

13. Vitali C, Bomardieri S, Jonsson R, Moutsopoulos HM, Alexander EL, Carson SE et al. Classification criteria for Sjögren's syndrome: a revised version of the European criteria proposed by the American European consensus group. Ann Rheum Dis. 2002;61:554-8.

15. Fujita N, Igarashi T,Kurai T, Sakane N, Yoshino S, Takahasi H. Correlation between dry eye and rheumatoid arthritis activity. Ophthalmology 2005;140:808-13.

Table 1 - Data in 82 rheumatoid arthritis patients with and without secondary Sjögren's syndrome

\begin{tabular}{lccc}
\hline & With SS & Without SS \\
$\mathrm{n}=20$ & $\mathrm{n}=62$ & $\mathrm{p}$ \\
\hline Mean disease duration (years) & $9.9 \pm 6.3$ & $10.4 \pm 7.2$ & 0.95 \\
Gender (female/male) & $18 / 2$ & $54 / 8$ & 1.00 \\
Rheumatoid factor & $14 / 20(70 \%)$ & $36 / 62(58 \%)$ & 0.24 \\
Anti CCP & $6 / 8(75 \%)$ & $19 / 27(70.3 \%)$ & 1.00 \\
Antinuclear antibody & $6 / 20(30 \%)$ & $19 / 62(30.6 \%)$ & 0.95 \\
\hline
\end{tabular}


16. Theander E, Jacobsson LTH. Relationship of Sjogren's syndrome to other connective tissue and autoimmune disorders. Rheum Dis Clin Noth Am. 2008;34:935-47.

17. Fox R. Sjögren's syndrome. Lancet 2005;366:321-30.

18. Carmona L, Gozalez-Alvaro I, Balsa A, Angel Belmonte M, Tena X, Sanmarti R. Rheumatoid arthritis in Spain: occurrence of extra-articular manifestations and estimates of disease severity. Ann Rheum Dis. 2003;62:897-900.
19. Uhlig T, Kvien TK, Jensen JL, Axéll T. Sicca symptons, saliva and tear production and disease variables in 636 patients with rheumatoid arthritis. Ann Rheum Dis. 1999;58:415-22.

20. Young A, Koduri G. Extra-articular manifestations and complications of rheumatoid arthritis. Best Pract Res Clin Rheumatol. 2007; 21:909-27.

21. Wolfe F, Michaud K. Prevalence, risk and risk factors for oral and ocular dryness with particular emphasis on rheumatoid arthritis. J Rheumatol. 2008;35:1023-30. 